UDC 621.313 .333

DOI: $10.30929 / 2072-2052.2018 .4 .44 .21-28$

\title{
EXPERIMENTAL STUDY ON IMPLEMENTATION OF COMPENSATION ALGORITHMS FOR FAULTY INDUCTION MOTORS
}

W. Castel

Institut catholique d'arts et métiers

Avenue de Grande Bretagne, 75, 31300, Toulouse, France. E-mail: william.castel@2019.icam.fr

D. Mamchur

Kremenchuk Mykhailo Ostrohradskyi National University

Pershotravneva, 20, Kremenchuk, 39600, Ukraine. E-mail: 3dm@ukr.net

Purpose. The design and implementation experimental setup for testing compensation algorithm aimed to control induction motors operated under damages or faults. Developed hardware and software solutions will allow us to test different compensation algorithms for different control types, such as vector and scalar control, which would be possible further implement as a part of industrial solutions. Methodology. Authors have analyzed theory of existing methods used for compensation induction motors faults and damages influence on their operation and power consumption. Best possible choice was to create compensation signals using control algorithms implemented into inverter control software. Authors have developed appropriate software solutions, implemented them basing on Microchip dsPICDEM MCHV-3 Development Board (High Voltage) for vector control of induction motor with windings asymmetry. Results. In the paper it was described the construction process of an experimental setup, as well as development and program implementation of control algorithm with compensation. As result, it were created both experimental setup and appropriate software which could be used as a basis for further investigation of other compensation methods and algorithms. Also, experimental results were derived for case of motor suffering from windings asymmetry, which confirmed theoretical assumptions and showed good accordance with simulation results available in references. Practical value. As result, it was developed experimental setup which could be used both for research and teaching purposes. References 5, figures 10 .

Key words: motor current signature analysis, instantaneous power signature analysis, field-oriented control, induction motor.

\section{ЕКСПЕРИМЕНТАЛЬНЕ ДОСЛІДЖЕННЯ ЩОДО ВПРОВАДЖЕННЯ АЛГОРИТМІВ КОМПЕНСАЦІЇ РОБОТИ АСИНХРОННИХ ДВИГУНІВ 3 ПОШКОДЖЕННЯМИ}

\section{В. Кастел}

Католицький інститут мистецтв і ремесел

просп. Великої Британії, 75, м. Тулуза, 31300, Франція. E-mail: william.castel@2019.icam.fr

\section{Д. Г. Мамчур}

Кременчуцький національний університет імені Михайла Остроградського

вул. Першотравнева, 20, м. Кременчук, 39600, Україна. E-mail: 3dm@ukr.net

Стаття присвячена питанням розробки експериментального зразка системи керування режимами роботи асинхронного двигуна, що має пошкодження або дефекти. На основі аналізу попередніх теоретичних досліджень було обрано методи виявлення дефектів за аналізом електричних сигналів, а також методи їх компенсації засобами систем керування на основі перетворювачів частоти. Для обраних методів компенсації за допомогою алгоритмів векторного керування перетворювачем частоти, було створено експериментальний зразок, включаючи його апаратне й програмне забезпечення для випадку компенсації несиметрії обмоток статора. На основі створеного зразка було проведено експериментальні дослідження, які підтвердили теоретичні дослідження i дозволили зробити висновок про доцільність використання створених алгоритмів і впровадження експериментального зразка у промисловості.

Ключові слова: сигнатурний аналіз струмів двигуна, сигнатурний аналіз миттєвої потужності, векторне керування, асинхронний двигун.

PROBLEM STATEMENT. Induction motor was invented in the second half of the XVII century by Nikolas Tesla. Today induction motor (IM) is one of the most common motor types. In fact, $50 \%$ of the total electric power consumption is due to IM and about $90 \%$ of the industrial motors are induction machine $[1-5,7]$. They are preferred to other type of motor for several reasons, such as: their reliability, their construction is quite simple, they can be speed controlled and their cost is relatively low. However, some failure can occur on this type of motor, due to a rude industrial environment. These failures can lead in some case to a total shutdown of the process. Also, if an IM operates in not good condition, it will consume extra-power and lead to economics losses for the company and bad environmental impact. That's why it is important to have an effective mean of failure detection, a solid IM diagnostic system even in operating condition. One of the most reliable methods used for IM fault detection is based on the analysis of electric signals. In our case we will study the motor current spectra analysis (MCSA) and the instantaneous power spectra analysis (IPSA) methods $[7,8]$. The MCSA is easier to set up but less reliable than the IPSA. In this paper we will try, in one hand, to 
make a diagnostic, by using analysis of electric signal, of unhealthy motor. In other hand, we will try to modify an $\mathrm{AC}$ induction motor control algorithm so that it can compensate for some problem on the motor and thus make it good enough to continue the process and/or reduce its power consumption.

EXPERIMENTAL PART AND RESULTS OBTAINED.

Types of failure and motor current spectra analysis

a) Air-gap eccentricity

Air-gap eccentricity is one of the most common faults in induction machine. It appears when there is an unequal air-gap between the stator and the rotor. There are 3 different types of air-gap eccentricity: static, dynamic and mixed. It is possible to detect this fault type by current spectrum analysis because it creates two type of current frequency. One around the principal harmonic and this other one around principle slot harmonic, these frequencies are given by [6]:

$$
f_{\text {eccen_fun }}=f_{s} \pm k f_{r}
$$

where $f_{r}=\frac{1-s}{p}$, where $s$ is the motor slip; $p$ is the number of pole pairs;

$$
f_{\text {eccen_prin }}=\left[\left(k R \pm n_{d}\right)\left(\frac{1-s}{p}\right)+\eta\right] f_{s},
$$

where $R$ is the number of rotor slots; $k$ is the positive integer number; $n_{d}$ is an integer due to dynamic eccentricity; $\eta$ is the time harmonics present in the motor supply.

b) Broken Rotor Bars

It is possible to detect broken rotor bar by current spectrum analysis, indeed it create some fundamental sidebands of the supply frequency and of the winding factor in the current signal, given by [6]:

$$
f_{b b}=f_{s}[1 \pm 2 s] \text {, }
$$

where $f_{s}$ is the supply fundamental frequency; $s$ is the motor slip.

c) Bearing Damage

During the conception process of an induction machine, some problem can occur and induce small damage on the bearing or defective installation. Those problems can lead to premature failures. We can see, in Fig. 1 [7], 4 different type of misalignment of the bearing. This bearing damages cause vibration and consequently air-gap eccentricity. It leads to variation in the stator current frequency, given by [1]:

$$
f_{b r g}=\left[f_{s} \pm m f_{i, o}\right],
$$

where $m=1,2,3 \ldots$ and $f_{i, o}$ is one of the characteristic vibration frequencies, which are based upon the bearing dimensions:

$$
f_{i, o}=\frac{n}{2} f_{v}\left[1 \pm \frac{b d}{p d} \cos \beta\right],
$$

where $n$ is the number of bearing balls; $f_{v}$ is the mechanical rotor velocity in hertz; $b d$ is the ball diameter; $p d$ is the bearing pitch diameter; $\beta$ is the contact angle of the balls on the races.

d) Stator windings short-turns

One other common fault is stator windings shortturns. This type of fault creates a negative magnetomotive force and cause a decrease of the total magnetomotive force of the motor. The waveform of air-gap flux is changed by the modification of the total magnetomotive force of the motor, which induces harmonic frequencies in a stator winding current given by [6]:

$$
f_{s t}=f_{s}\left[\frac{n}{p}(1-s) \pm k\right]
$$

where $f_{s}$ is the supply main frequency; $n$ is a positive integer number $(1,2,3 \ldots) ; s$ is the motor slip; $k$ can be equal to $1,3,5$ or 7 .

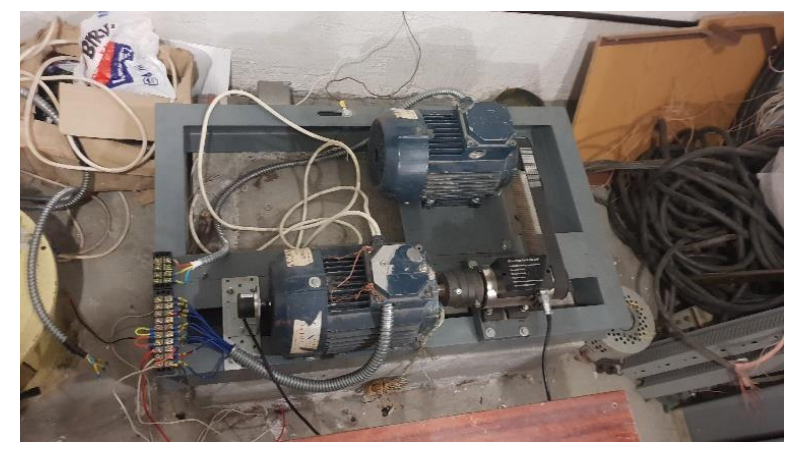

a)

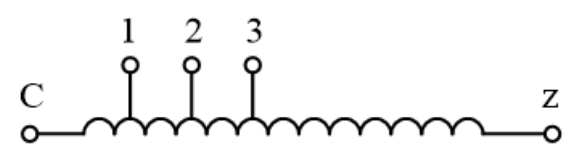

b)

Figure 1 - Motor used for experiment (a) and stator phase windings taps circuits (b)

\section{Instantaneous power spectra analysis}

It is also possible to analyze the instantaneous power spectra to detect motor faults. This method not only allows us to find out fault but also to estimate the level of damage, by analysis of the proper harmonic value. Additionally, instantaneous power spectra analysis is more reliable.

Like in the other method, we could find motor fault by making a comparison with the spectra of a healthy motor, and then associated some fault with harmonic at unique frequencies given by formulas.

We first can write the following equation [6]:

$$
\begin{aligned}
& p(t)=u(t) i(t)=2 U_{1} I_{1} \cos (\omega t) \cos (\omega t-\phi)= \\
& =2 U_{1} I_{1} \cos (\omega t)\left[\begin{array}{l}
\cos (\omega t) \cos (\phi)+ \\
+\sin (\omega t) \sin (\phi)
\end{array}\right]= \\
& =U_{1} I_{1} \cos (\phi)+U_{1} I_{1} \cos (\phi) \cos (2 \omega t)+ \\
& +U_{1} I_{1} \sin (\phi) \sin (2 \omega t),
\end{aligned}
$$

where $U_{1}, I_{1}$ are RMS values of phase voltage and current, respectively; $\omega=2 \pi f_{s}$ is the angular frequency, 
where $f_{s}$ is the supply frequency; $\phi$ is the motor load angle.

To make a right analysis of the power spectra we must sum each instantaneous phase of power spectra to have the total power [6]:

$$
p_{t o t}(t)=u_{A}(t) i_{A}(t)+u_{B}(t) i_{B}(t)+u_{C}(t) i_{C}(t) .
$$

a) Air-gap eccentricity

As said above, air-gap eccentricity create some sideband frequency, the phase current and de phase instantaneous power can be written as [6]:

$$
\begin{aligned}
& i_{\text {eccen }}(t)=i(t)+ \\
& +\frac{\sqrt{2}}{2} I_{1} \sum_{k=1}^{K}\left[\begin{array}{l}
I_{e 1 k} \cos \left(2 \pi\left(f_{s}-k f_{r}\right) t-\alpha_{e 1 k}\right)+ \\
+I_{e 2 k} \cos \left(2 \pi\left(f_{s}+k f_{r}\right) t-\alpha_{e 2 k}\right)
\end{array}\right],
\end{aligned}
$$

where $I_{e 1 k}, \alpha_{e 1 k}$ are the current amplitudes and the initial phase angle for frequencies $f_{s}-k f_{r} ; I_{e 2 k}, \alpha_{e 2 k}$ are the current amplitudes and the initial phase angle for frequencies $f_{s}+k f_{r}$.

$$
\begin{aligned}
& p_{\text {eccen }}(t)=i_{\text {eccen }}(t) u(t)=P_{0}+U_{1} I_{1} \cos (\phi) \cos (2 \omega t)+ \\
& +U_{1} I_{1} \sin (\phi) \sin (2 \omega t)+ \\
& +\sqrt{2} U_{1} \cos (2 \omega t) \sum_{k=1}^{K}\left[\begin{array}{l}
I_{e 1 k} \cos \left[\begin{array}{l}
2 \pi\left(f_{s}-k f_{r}\right) t- \\
-\alpha_{e 1 k}-\phi
\end{array}\right]+ \\
+I_{e 2 k} \cos \left[\begin{array}{l}
2 \pi\left(f_{s}+k f_{r}\right) t- \\
-\alpha_{e 2 k}-\phi
\end{array}\right]
\end{array}\right]
\end{aligned}
$$

b) Broken Rotor Bars

The broken rotor bars create sinusoidal modulation in the stator current, the modification in the phase current and instantaneous power phase are given by [6]:

$$
\begin{aligned}
& i_{m}(t)=i(t)\left[1+I_{m} \cos \left(2 \pi f_{b b} t\right)\right]= \\
& =i(t)+\frac{\sqrt{2}}{2} I_{1} I_{m}\left[\begin{array}{l}
\cos \left(2 \pi\left(f_{s}-f_{b b}\right) t-\phi\right)+ \\
+\cos \left(2 \pi\left(f_{s}+f_{b b}\right) t-\phi\right)
\end{array}\right],
\end{aligned}
$$

where $I_{m}$ is the modulation index; $f_{b b}$ is the modulating frequency; $s$ is the motor slip.

$$
\begin{aligned}
& p_{m}(t)=i_{m}(t) u(t)= \\
& =P_{0}+U_{1} I_{1} \cos (\phi) \cos (2 \omega t)+ \\
& +U_{1} I_{1} \sin (\phi) \sin (2 \omega t)+ \\
& +\left(\begin{array}{c}
I_{1} I_{m} U_{1} \cos \left[2 \pi\left(f_{s}-f_{b b}\right) t-\phi\right]+ \\
+I_{1} I_{m} U_{1} \cos \left[2 \pi\left(f_{s}+f_{b b}\right) t-\phi\right]
\end{array}\right) \cos (2 \omega t) .
\end{aligned}
$$

c) Bearing Damage

The vibration caused by a bearing damage create a current modulation at frequencies saw in $[5,6]$.

$$
\begin{aligned}
& i_{b r g}(t)=i(t)+ \\
& +\frac{\sqrt{2}}{2} I_{1} \sum_{k=1}^{K}\left[\begin{array}{l}
I_{b 1 k} \cos \left(2 \pi\left(f_{s}-k f_{b r g}\right) t-\alpha_{b 1 k}\right)+ \\
+I_{b 2 k} \cos \left(2 \pi\left(f_{s}+k f_{b r g}\right) t-\alpha_{b 2 k}\right)
\end{array}\right],
\end{aligned}
$$

where $I_{b 1 k}, \alpha_{b 1 k}$ are the current amplitudes and the initial phase angle for frequencies $f_{s}-k f_{b r g}$; $I_{b 2 k}, \alpha_{b 2 k}$ are the current amplitudes and the initial phase angle for frequencies $f_{s}+k f_{b r g}$.

$$
\begin{aligned}
& p_{b r g}(t)=i_{b r g}(t) u(t)=p_{0}(t)+ \\
& +\frac{1}{2} I_{1} U_{1} \sum_{k=1}^{K}\left[\begin{array}{l}
I_{b 1 k} \cos \left[\begin{array}{l}
2 \pi\left(2 f_{s}-k f_{b r g}\right) t- \\
-\alpha_{b 1 k}
\end{array}\right]+ \\
+I_{b 2 k} \cos \left[\begin{array}{l}
2 \pi\left(2 f_{s}-k f_{b r g}\right) t- \\
-\alpha_{b 2 k}
\end{array}\right]+ \\
+I_{b 1 k} \cos \left(\alpha_{b 1 k}\right) \cos \left(k f_{b r g} t\right)+ \\
+I_{b 2 k} \cos \left(\alpha_{b 2 k}\right) \cos \left(k f_{b r g} t\right)
\end{array}\right]
\end{aligned}
$$

d) Stator windings short-turns

One more time we could write the stator current phase and the instantaneous power phase as [6]:

$$
\begin{aligned}
& i_{m}(t)=i(t)\left[1+I_{m} \cos \left(2 \pi f_{s t} t-\phi\right)\right]= \\
& =i(t)+\frac{\sqrt{2}}{2} I_{1} I_{m}\left[\cos \left(2 \pi f_{s t} t-\phi\right)\right],
\end{aligned}
$$

where $I_{m}$ is the modulation index; $f_{s t}$ is the modulating frequency; $s$ is the motor slip.

$$
\begin{aligned}
& p_{m}(t)=i_{m}(t) u(t)=P_{0}+U_{1} I_{1} \cos (\phi) \cos (2 \omega t)+ \\
& +U_{1} I_{1} \sin (\phi) \sin (2 \omega t)+ \\
& +\frac{1}{2} I_{1} I_{m} U_{1} \cos \left(2 \pi f_{s t} t-\phi\right) \cos (2 \omega t) .
\end{aligned}
$$

\section{Our equipment}

Some equipment is required to create our IM diagnostic system. We need a part which will gather the electric signal from our motors (the hardware) and a part which will analyze this information and interact with the induction motor (the software).

a) The hardware

To develop our algorithm, we must test healthy motor and motor with damages or faults. For testing our program during the development phase of the algorithm we used an AC induction motor of type AIRM63A4U2 $\mathrm{I}, 0.25 \mathrm{~kW}$. This motor allows us to test our program and see if the waveform of our compensation current was consistent.

The motor used to realize our experiment was an AC induction motor of the type AIR80V4U2, $1.5 \mathrm{~kW}$. To recreate the effect of a stator winding asymmetry, to imitate stator winding short turns, we used taps provided in one phase of the stator winding (phase A in our case), we could see the influence of this taps in the table in Fig. 1 [6].

To control the motors, we used a dsPICDEM MCHV-3 Development Board (High Voltage). This board designed by Microchip allows us to control many types of motors such as Brushless DC (BLDC) motors, Permanent Magnet Synchronous Motors (PMSM), and AC Induction Motors (ACIM) in sensor or sensorless operation. This board can be connected to a personal computer thanks to two USB wires. We can see this board alone and plug with a motor in Fig. 2 . 


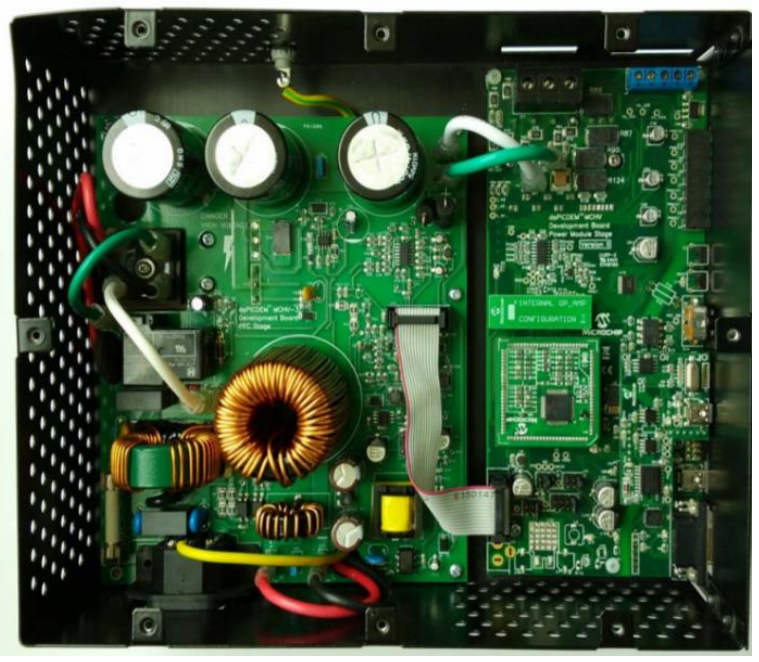

a)

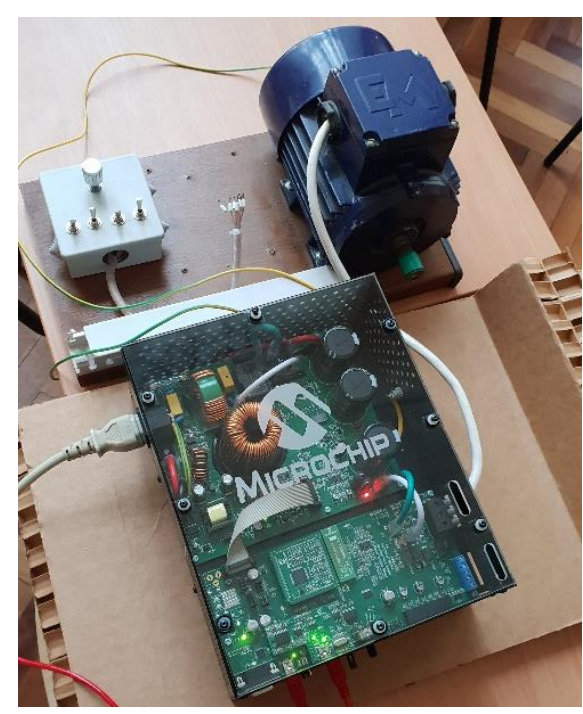

b)

Figure 2 - Development board (a) and testing setup (b)

b) The software

To have a base to develop our program, we had to find an algorithm capable of controlling AC induction motor. There are several control algorithms exist but we focused on a program which used sensorless field oriented control (FOC) method (find on: https://www.microchip.com).

We develop our algorithm on the software MPLAB $\mathrm{X}$ IDE v5.05 with the compiler XC16.

Development of our algorithm

a) Correction of an IM with Asymmetrical Stator Windings

In this paper we will study the correction of operating mode of an induction motor with stator windings problems. Those problems in stator windings lead to variable components of electromagnetic torque and consumed power and could lead to an oscillation of motor torque and speed, which can make the IM totally useless. Thanks to $[9,10]$, we could see two possibilities to correct this fault in stator windings. One method consists of the compensation of the electromagnetic torque variable component, and the other one act on the consumed active power variable component. During the phase of development of our algorithm we looked at both methods.

b) Compensation of the electromagnetic torque variable component

We could learn in [9] that the electromagnetic torque of an induction motor with stator asymmetric windings is the sum of a constant and a variable component: $T_{e}=T_{e 0}+T_{\mathrm{var}}$. The first method consists in compensation of this variable component of $T_{e}$ in order to reduce the influence of the asymmetrical stator winding.

We then could write the value of the variable components as:

$$
T_{\mathrm{var}}=T_{e}-\frac{1}{T} \int_{0}^{T} T_{e} d t
$$

where $T_{e}$ is the electromagnetic torque; $T$ is the signal period of the variable component of electromagnetic torque.

This value of $T_{\mathrm{var}}$ is then sent to the regulator of torque-generating component $I_{s q}$ of the stator current. So, according to the paper [9], we could write the compensation current as:

$I_{s q}^{\prime}=I_{s q}-k_{i} T_{\mathrm{var}}$, where $k_{i}$ is a reduction coefficient.

The electromagnetic torque $T_{e}$ is not easy to measure directly, so we can use a formula to determine it:

$$
T_{e}=\frac{3}{2} Z_{p} \frac{L_{\mu}}{L_{\gamma \sigma}+L_{\mu}}\left|\psi_{\gamma}\right| I_{s q},
$$

where $\Psi_{r}$ is the rotor flux; $z_{p}$ is the number of pairs of poles; $I_{s q}$ is the stator $q$ axes current.

After studying this method and try to implement it in our program, as far as this method deals with compensation for torque signal, the best way for experimental verification is to use torque sensor, which determines special recomposition of experimental setup. That's why at first, we decided to verify another method, for compensation of instantaneous power variable component, which does not need any change in experimental setup.

b) Compensation for variable component of consumed active power

From [9], we've learned about the method to create a compensation current for reduce the influence of the asymmetrical stator winding based on the use of Park and Clark's transformation.

In this method we change from signals of phase currents and voltages in a fixed coordinate system to a rotating coordinate system by the following relations [9]:

$$
\left[\begin{array}{l}
I_{s d} \\
I_{s q}
\end{array}\right]=\frac{1}{\sqrt{U_{s \alpha}^{2}+U_{s \beta}^{2}}}\left[\begin{array}{cc}
U_{s \alpha} & U_{s \beta} \\
-U_{s \beta} & U_{s \alpha}
\end{array}\right]\left[\begin{array}{c}
I_{s \alpha} \\
I_{s \beta}
\end{array}\right],
$$

where $U_{s \alpha}, U_{s \beta}, I_{s \alpha}, I_{s \beta}$ are projection of voltage and current vector in a fixed coordinate system; $I_{s d}, I_{s q}$ are projection of current vector in an orthogonal rotating coordinate system.

The obtained values $I_{s d}$ and $I_{s q}$ can be written as a 
sum of a fix component and a variable component [9]:

$$
I_{s d}=I_{s d 0}+I_{d \mathrm{var}} ; I_{s q}=I_{s q 0}+I_{q \mathrm{var}} .
$$

We've calculated our compensation current in the following way [9]:

$$
\left[\begin{array}{l}
I_{c \alpha} \\
I_{c \beta}
\end{array}\right]=\frac{1}{\sqrt{U_{s \alpha}^{2}+U_{s \beta}^{2}}}\left[\begin{array}{ll}
U_{s \alpha} & -U_{s \beta} \\
U_{s \beta} & U_{s \alpha}
\end{array}\right]\left[\begin{array}{l}
-I_{d \mathrm{var}} \\
-I_{q \mathrm{var}}
\end{array}\right] .
$$

Finally, after transformed the obtained signal into a rotating system by direct Clark transformation we add the output signal to the referential currents:

$$
I_{s d}^{\prime}=I_{s d(r e f)}+I_{c d} ; I_{s q}^{\prime}=I_{s q(r e f)}+I_{c q} .
$$

In our basic algorithm, provided typical solutions for IM vector control, we have access to all the information necessary to the application of proposed compensation method, $U_{s \alpha}, U_{s \beta}, I_{s \alpha}, I_{s \beta}$. We could see in Fig. 3, the block diagram of our algorithm which could be find in the document "AN1162: Sensorless Field Oriented Control (FOC) of an AC Induction Motor (ACIM)". This diagram will allow us to see where we must implement this method to create our compensation current.

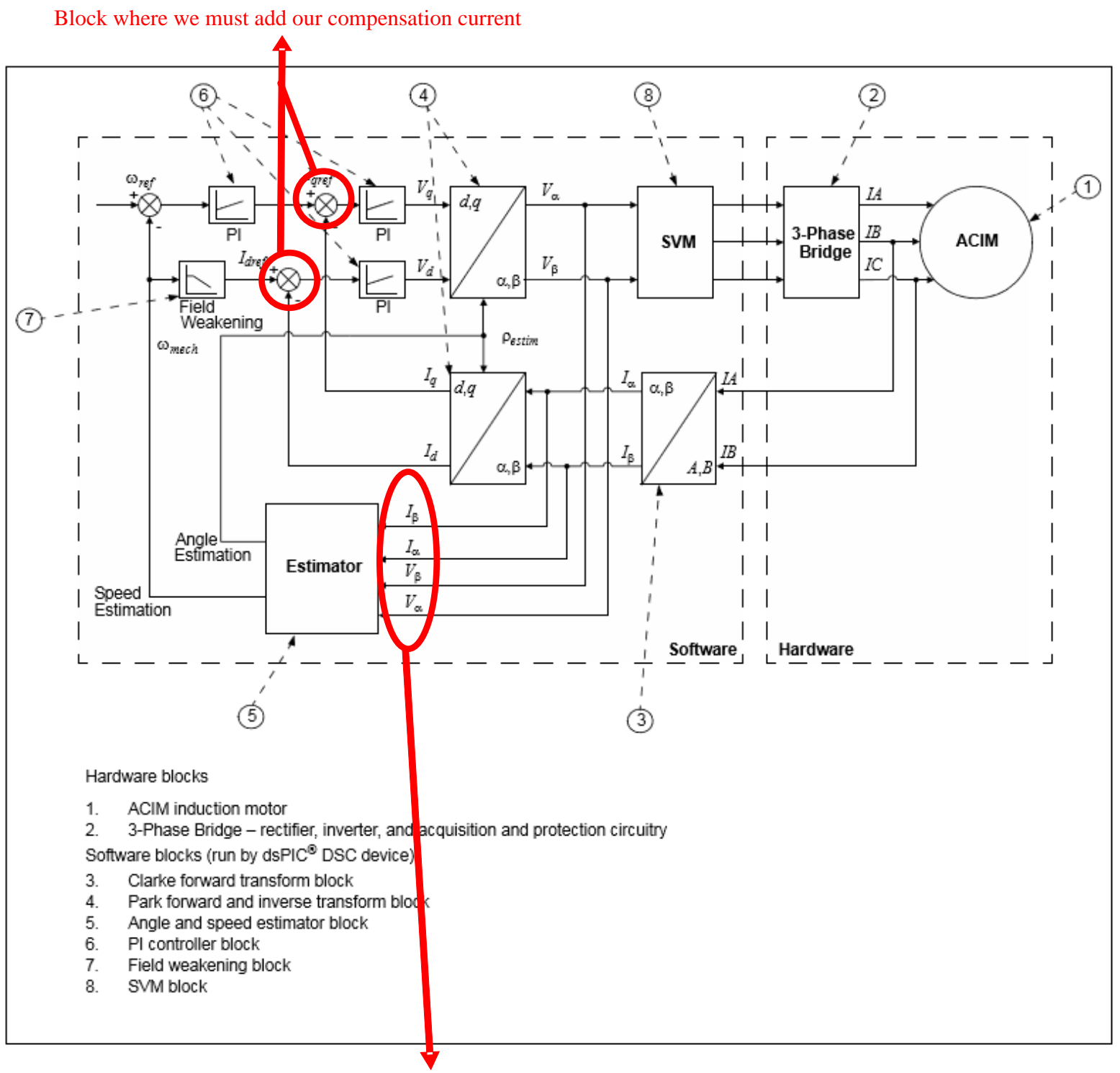

Values we need for calculations

Figure 3 - Block diagram of compensation algorithm

a) Simulink model

In order to create our algorithm and get some theorical result we used the following Simulink model with the 3 functions who allow us to calculate our compensation current by compensation for variable component of consumed active power method. b) The algorithm

Our algorithm is based on the Field Oriented Control (FOC) also known as "vector control". The FOC is a variable frequency drive control method where the three-phase stator current of the AC induction motor is transformed in two orthogonal components which can be considered like vectors (Fig. 4). 


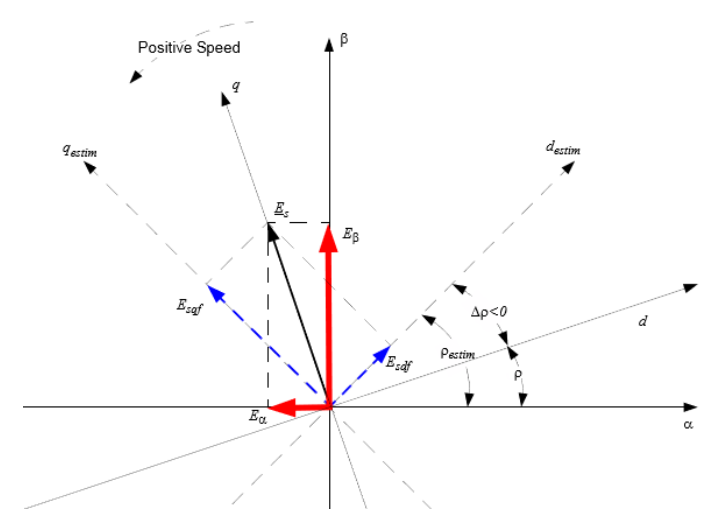

Figure 4 - Vector diagram for field oriented control algorithm

The first vector represents the magnetic flux, while the second represent the torque. The control system calculates the torque and the electromagnetic flux necessary from the speed instruction and then find the corresponding current. Proportional integral (PI) controllers are used to the measured current components at their reference values. Finally, a Pulse-Width Modulation (PWM) manages the switching of the transistors of the electric speed controller according to the voltage input instruction. This method had the advantage to be rapid and accurate.

Our first task was to adapt our algorithm in order to use Data Monitor and Control Interface (DMCI), DMCI is a tool provide in MPLAB, allowing the user to visualize some graphics an to change some variable while the motor is running. We created a flag for turn on and shut off the induction motor and a variable "Speedreference" in order to change the rotational speed. The DMCI helping us a lot during the development phase because it permits us to visualize the variable we created and to see if they we're absurd or not.

Then we start to implement our own functions to calculate this compensating current needed to reduce the impact of asymmetrical stator winding. We conceived a new header file and a source file name respectively Comp.h and Compensate.c where we could put our functions.

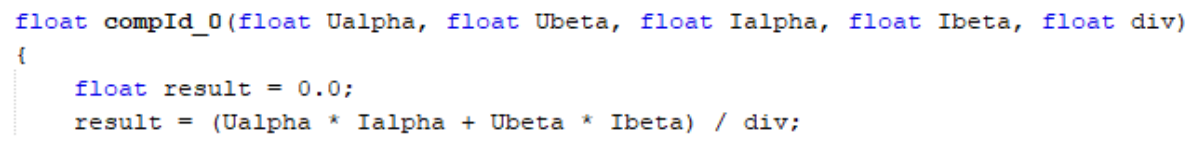

Those two functions calculate the mean value of Isd. We use this mean value to calculate the variable components Idvar, by doing a subtraction between Isd and its mean values:

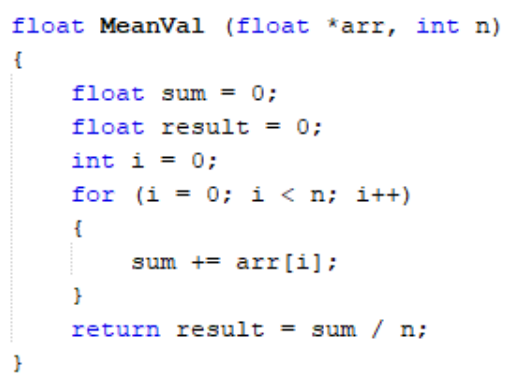

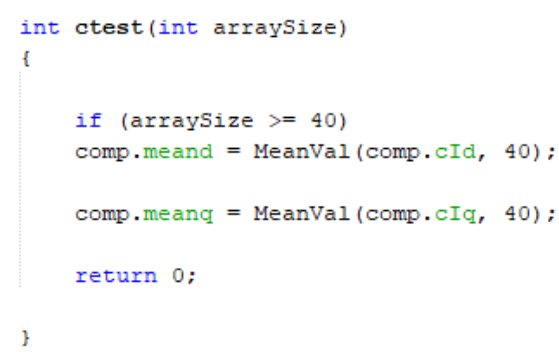

In this last function calc_0(), we gather all the components we need in the different array, and we inject this values in the functions using the formulas seen previously, in order to calculate our final value of compensation current: 


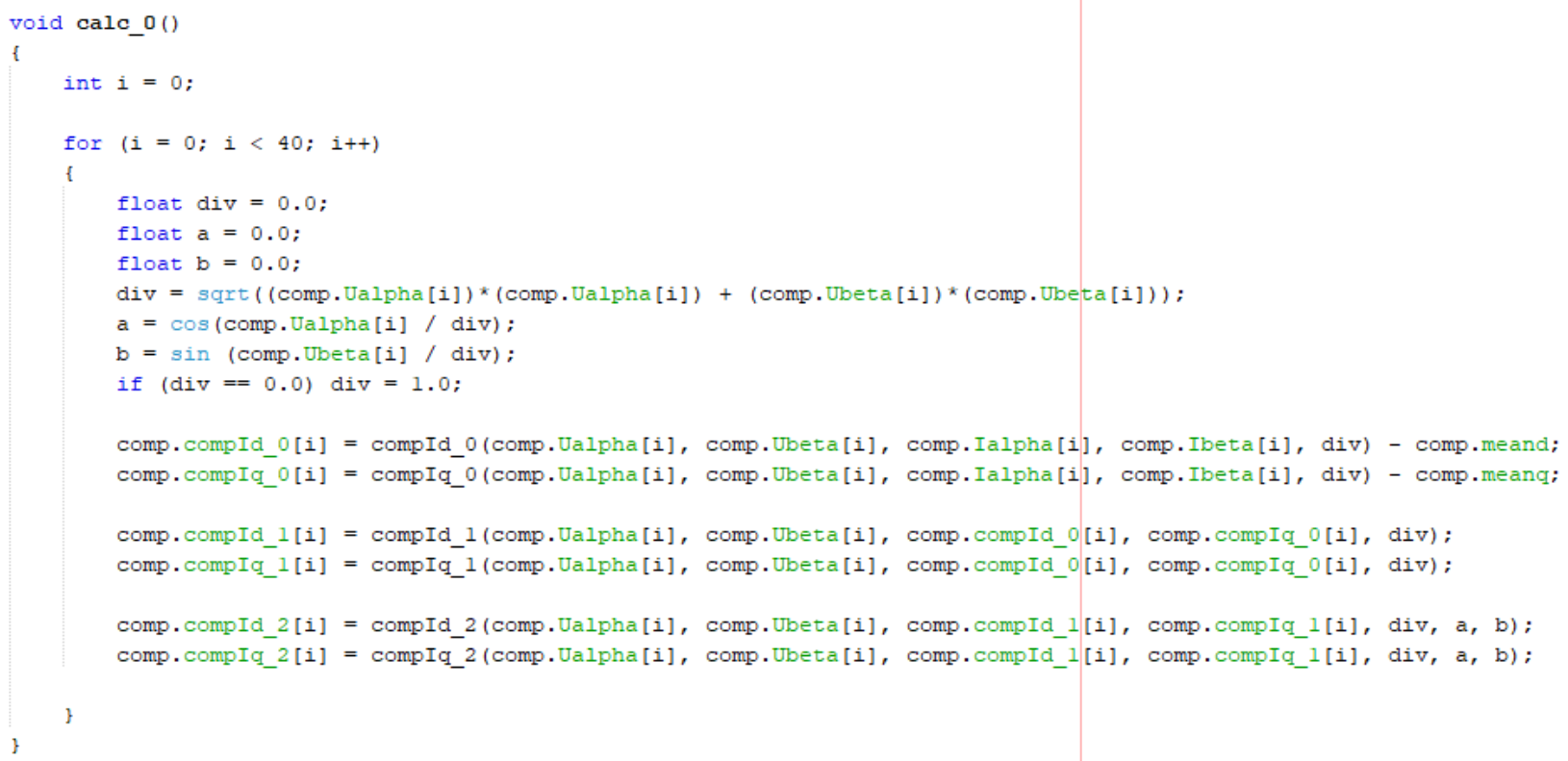

For the sake of speed of calculation, we used array of only 40 values.

\section{Experiment}

The material at our disposal for the experiment allow us to create several cases of study. We get data from four different situations:

- healthy motor, with and without compensation current;

- motor with $14.2 \%$ of asymmetry in one of stator windings phase, with and without compensation current;

- healthy motor loaded, with and without compensation current;

- motor with $14.2 \%$ of asymmetry in one of stator windings phaseand loaded, with and without compensation current.

Basing on experimental results analysis (Fig. 5), we can make several conclusions.

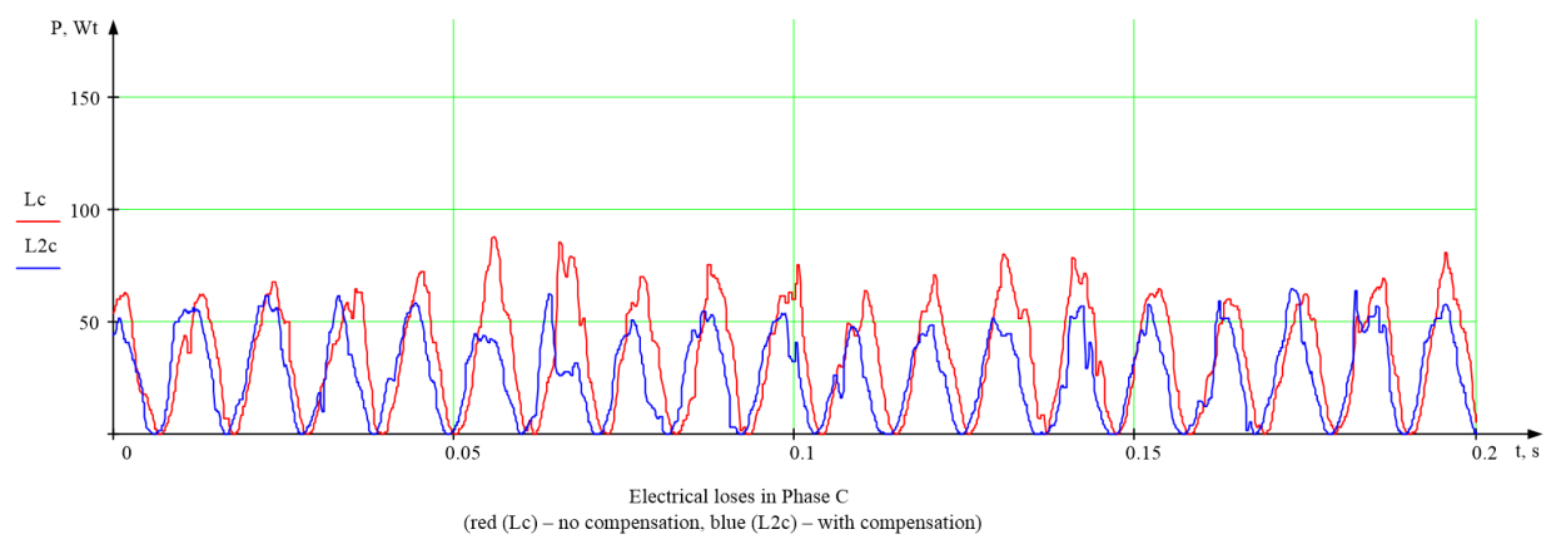

Figure 5 - Experimental values of electrical loses for unsymmetrical motor (14\% asymmetry in phase C) without (Lc) and with (L2c) use of compensation algorithm

Here it is quite clear that the stator winding losses decrease significantly with the compensation current injected. We could notice that the losses are bigger in the phase A, this could be explained by the fact of the asymmetry in the stator windings is create on the phase A. In order to have a more precise idea of how much we decrease the losses in the motor with our algorithm we could compare the stator winding losses with a motor without asymmetry.

CONCLUSIONS. Induction motors can encounter various problems throughout their activity. We have seen in this paper what these problems were, and how to detect them with the spectral analysis methods. We also looked at a precise case: asymmetrical stator windings, we saw two methods to correct this problem, and we tried to apply these methods to create a compensation algorithm. We then test this program on laboratory.

A motor controlled by our algorithm, using the "compensation for variable component of consumed active power" method, shown a net decrease of the losses compare to a motor without compensation.

We can conclude, this algorithm allows us to reduce the consumption of a damaged induction motor and could also extend its operating life, but some improve- 
ment can be done to make this algorithm even more performant. One axe can be to create a function which "synchronize" the period of the sampled signals and the period of the compensation current calculated, it's will probably increase the efficiency of the algorithm.

\section{REFERENCES}

1. Legowski, S.F., Sadrul Ula, A.H.M. and Trzynadlowski, A.M. (1996), "Instantaneous power as a medium for the signature analysis of induction motors," IEEE Transactions on Industrial Electronics, Vol. 32, no. 4, pp. 904-909.

2. Trzynadlowski, A.M. and Ritchie, E. (2000), "Comparative investigation of diagnostic media for induction motors: a case of rotor cage faults," IEEE Transactions on Industrial Electronics, Vol. 47, no. 5, pp. 1092-1099.

3. Drif, M. and Cardoso, A.J.M. (2009), "The use of the instantaneous-reactive-power signature analysis for rotor-cage-fault diagnostics in three-phase induction motors," IEEE Transactions on Industrial Electronics, Vol. 56, no. 11, pp. 4606-4614.

4. Jung, J.H., Jong-Jae, Lee and Bong-Hwan, Kwon, (2006), "Online diagnosis of induction motors using MCSA," IEEE Trans. on Industrial Electronics, Vol. 53, pp.1842-1852.

5. Wang, Li, Wang, Xuan and Wei, Min (2010), "Motor bearing fault diagnosis based on wavelet packet decomposition of instantaneous power," in Proc. International Conference on Computer Design and Applica- tions (ICCDA 2010), pp. V3-457-V3-459.

6. Zagirnyak, M., Mamchur, D. and Kalinov, A. (2014), "Induction Motor Diagnostic System Based on Spectra Analysis of Current and Instantaneous Power Signals", Materials of the IEEE SoutheastCon 2014, Lexington, pp. 1-7.

7. Benbouzid, M.E.H. (2000), "A review of induction motors signature analysis as a medium for faults detection", IEEE Transactions on Industrial Electronics, Vol. 47, no. 5, pp. 984-993.

8. Zagirnyak, M.V., Mamchur, D.G. and Kalinov A.P. (2012), "Comparison of induction motor diagnostic methods based on spectra analysis of current and instantaneous power signals", Przeglad Elektrotechniczny, Iss. 12b/2012, pp. 221-224.

9. Zagirnyak, M., Kalinov, A., Melnykov, V. and Kochurov, I. (2015), "Correction of the Operating Modes of an Induction Motor with Asymmetrical Stator Windings at Vector Control", 2015 International Conference on Electrical Drives and Power Electronics (EDPE) (7th Join Slovakian-Croacian Conference) Program and Abstracts, Tatranska Lomnica, The High Tatras, Slovakia, pp. 38-39.

10. Zagirnyak, M., Kalinov, A. and Chumachova, A. (2013), "Correction of operating condition of a variablefrequency electric drive with a non-linear and asymmetric induction motor", Proceedings of International IEEE Conference EUROCON 2013, Zagreb, Croatia, pp. 1033-1037.

\section{ЭКСПЕРИМЕНТАЛЬНЫЕ ИССЛЕДОВАНИЯ ВНЕДРЕНИЯ АЛГОРИТМОВ КОМПЕНСАЦИИ РАБОТЫ АСИНХРОННЫХ ДВИГАТЕЛЕЙ С ПОВРЕЖДЕНИЯМИ}

\section{В. Кастел}

Католический институт искусств и ремёсел

просп. Великой Британии, 75, г. Тулуза, 31300, Франция. E-mail: william.castel@ 2019.icam.fr

Д. Г. Мамчур

Кременчугский национальный университет имени Михаила Остроградского

ул. Первомайская, 20, г. Кременчуг, 39600, Украина. E-mail: 3dm@ukr.net

Статья посвящена вопросам разработки экспериментального образца системы управления режимами работы асинхронного двигателя, имеющего повреждения или дефекты. На основе анализа предыдущих теоретических исследований были выбраны методы выявления дефектов на основе анализа электрических сигналов, а также методы их компенсации средствами систем управления на основе преобразователей частоты. Для выбранных методов компенсации при помощи алгоритмов векторного управления преобразователем частоты был создан экспериментальный образец, включающий аппаратное и программное обеспечение для случая компенсации несимметрии обмоток статора. На основе созданного образца были проведены экспериментальные исследования, которые подтвердили теоретические изыскания и позволили сделать вывод о целесообразности использования созданных алгоритмов и внедрения экспериментального образца в промышленных условиях.

Ключевые слова: сигнатурный анализ токов двигателя, сигнатурный анализ мгновенной мощности, векторное управление, асинхронный двигатель.

Стаття надійшла 26.10.2018. 